\title{
The Coherence Model of Self-Efficacy as the Intervening Variable of Work Environment and Leadership Behavior on the Employees Performance of Aceh Government Planning Agency
}

\author{
Em Yusuf Iis ${ }^{1}$, Sulaiman $^{2}$ and Ahadi Arifin ${ }^{3}$ \\ \{yusufiis@yahoo.co.id ${ }^{1}$, naraseuki.leman@gmail.com ${ }^{2}$, ahadiarifin88@gmail.com ${ }^{3}$ \} \\ ${ }^{1}$ Lecturer in Post Graduate Studies with Economics Faculty at Malikussaleh University, Aceh-Indonesia \\ ${ }^{2}$ Lecturer Undergraduate in Business Administration Study Program, Social and Political Sciences \\ Faculty at Al Muslim University, Indonesia \\ ${ }^{3}$ Lecturer in Post Graduate Studies with Economics Faculty at Malikussaleh University, Aceh-Indonesia
}

\begin{abstract}
This study examines the influence of leadership behavior, and work environment on self-efficacy and employee performance, and examines the mediation effects of self-efficacy. The sample in this study is 128 civil servants at the Regional Planning Agency of Aceh Province. The analysis tool used is path analysis with the SEM method (structural equation modeling) using Amos. The results show that leadership behavior, and work environment has a positive and significant effect on self-efficacy, and performance and self-efficacy mediate both exogenous variables with the endogenous variable in partial mediation.
\end{abstract}

Keywords: Leadership Behavior, Work Environment, Self-Efficacy, and Employee Performance

\section{Introduction}

The civil servants as elements of the state apparatus have a significant contribution in determining the success of the development. The role of civil servants is increasingly changing, and technology is increasingly complex and requires the civil servants to be adaptive to changes in their environment. In connection with this, a reliable leader must be able to adjust the organization both inside and outside of the organizational environment. The resources are very important and strategic elements to improve the performance of government employees. Performance is difficult to improve, especially because of the difficulty of imposing sanctions on the employees who are underperforming and also difficult to give awards to them with high-performance, (Bernandin and Russel, 2013). The position and role of civil servants as elements of the state apparatus have a significant contribution in determining the success of the development. The role of civil servants is entering an increasingly changing world, increasingly complex technology, and is a strategic resource as a professional management in regulating government governance that is always adaptive to the changing environment, (Ulrich et al., 2012), the role of source management human power as a strategic partner, a change agent, an employee champion, and as an administrative expert to be used to develop the strategic role of human resource management in accordance with the government organizations. Government and private organizations in achieving the stated goals can utilize the facilities within the organization that can be driven by a group of people playing an active role as actors in achieving organizational goals. In connection with this, a 
reliable leader must be able to adjust an organization both inside and outside the organizational environment.

The performance of an organization can measure the level of ability to carry out organizational tasks in order to achieve goals. The issue of this problem needs to be anticipated early so that the employee performance can be improved, (Armstrong, 2014). Work environment and employee performance have a strong and significant relationship with employee performance, which is efficient and effective in handling the workload of employees in Pakistan. Considering the strong enough relationship between self efficacy and performance in general, this study aims to find out more about the relationship between self-efficacy and performance. The Regional Development and Planning Agency (Bappeda) of Aceh Province is responsible to plan and control the regional development. The regional development and planning agency as the coordinator of the planning of development activity programs also has the task of controlling, monitoring, evaluating and coordinating cross-sectoral development activities. Therefore, the regional planning and development agency requires employees who are truly capable and in accordance with the duties and authorities that are their responsibility.

The problem and challenge faced by the Regional planning and development agency of Aceh Province are the limited ability of employees to achieve the mission and vision of the institution. To overcome that, the real and hard efforts of leaders and institutions are needed to create reliability and the realization of qualified employees so that the organizational goals are achieved based on the established standards. If the limited ability of employees continues to be left, then the performance of employees will decline and this will affect the overall performance of the institution. The issue as a phenomenon that has been occurring in the Regional Planning and Development Agency of Aceh Province has decreased the performance of employees which is marked by the completion of the activity budget accountability report, where the reports often exceed the given time limit. Annual Government Accountability Performance Report (LAKIP) (previous year) should have been submitted at the beginning of the current year but it has not been submitted to the Aceh provincial planning office until February. Individual employee performance is influenced by the internal and external environment where the employee works (Armstrong, 2014). The existing work environment will ensure occupational safety and health for them and will contribute to encourage individual performance and the performance of an organization. The relationship between employees in the work environment is still not harmonious. The authority has been given still not been realized by employees so that they sometimes do not make a decision as their rights. In the ranks of the Aceh government, there has been a standard and organizational procedure for employees in accordance with their respective fields of duty. Based on some of the opinions above, it can be concluded that there are still differences in the opinions of experts about the factors that influence performance.

In addition, (Rampersad, 2006; Bernandin and Russel, 2013) focus more on the external factors as the variables affecting the individual performance. Empirically, some previous studies examine the influence of leadership behavior including work environment and selfefficacy on performance such (Sharif, Ashraf and Khan, 2013). (Jayaweera, 2015) on a research finds that the work environment and performance have a significant effect on employee performance in Bristol Hotels in England. It concludes that the findings of previous studies are still not consistent where there are still differences in research results. Some studies reveal a positive and significant influence on employee self-efficacy, work environment, and leadership behavior on performance. Meanwhile, some of the results of other studies indicate that there are differences in the direction of the relationship and the level of significance of the influence between leadership behavior, work environment, and self-efficacy on employee 
performance. They also implement a restructuring strategy which is often referred to as downsizing or delayering in practice reducing the number of workers, work units or divisions or reducing the level of position in the organizational structure of the company. Reduction of company staff is needed for efficiency and effectiveness.

The performance of the employees at the regional planning and development agency is also influenced by the behavior of management as the leader and has a central role in achieving the organizational goals. Leaders are the determinants, communicators, mediators, and integrators in achieving organizational goals. Leaders will not succeed as leaders if they cannot motivate, move and satisfy employees in a job in a particular work environment. The training program is expected to improve employee competency. High competence employees can be seen in the increase in work attitudes, knowledge, skills, work responsibilities, and work discipline. In the practice of the Development planning agency of Aceh Government in order to improve employee performance, the work environment and self-efficacy are prioritized as a focus in leadership behavior. In fact, it shows that these two approaches have not had a significant impact on the performance of employees in the Aceh government. Based on the background and identification of the research problems above, the authors aim to know the influence of leadership behavior and work environment on self-efficacy and employee performance, to know the mediation effect of self efficacy on the relationship between leadership behavior and employee performance, and to know the mediation effect of self efficacy on the relationship between work environment on the performance of employees at the Aceh Province Regional Planning Agency.

\section{Methodology}

Employee performance depends on the ability of employees, their knowledge of a job, the disposition and threat, emotions, moods, effects, as trusts and values. (Kreitner and Kinicki, 2004, p. 205). Performance is a result of work achieved by a person in carrying out a task assigned based on skill, experience, sincerity and time (Wood, 1998, p. 91; Hasibuan and Malayu, 2008) define employee performance as a function of individual attributes, work effort, organizational supports. With the Job performance formula = Attribute attributes $\mathrm{X}$ Work effort X Organizational support. Employee performance is $\mathrm{f}$ (individual attributes, work effort, and organizational support). Employee performance is the "way of thinking about employee performance which is a function of the interaction of ability, motivation, and opportunity". In this case, employee performance is as a function of interaction ability, motivation, and opportunities for performance. Performance refers to several indicators according to (Mangkunegara, 2005) and (McDonald and Lawton, 1977), among others, as follows: (1) Quality of Work, (2) Quantity of work, (3) Reliable, (4) Attitude.

\subsection{Self-Efficacy}

Self-Efficacy is the result of cognitive processes in the form of decisions, beliefs, or rewards about the extent to which individuals estimate their abilities in carrying out certain tasks or actions needed to achieve the desired results (Bandura, 1994). Self-efficacy as a belief in the ability of somebody to regulate and carry out the actions needed to produce the achievement of goals. Self-efficacy is described as a cognitive mechanism that mediates behavior and can also influence participation in various behaviors. Self-efficacy determines the amount of effort and level of persistence in pursuing the behaviour. Self-Efficacy refers to several indicators according to (Bandura, 1994), (1) Magnitude of self-efficacy, (2) Strength of self-efficacy, (3) Generality of self-efficacy. 


\subsection{Leadership Behavior}

Leadership Behavior is the behavior or actions of a leader that can influence others in achieving a goal in accordance with the organizational situation (Hersey and Blanchard, 1994, p. 73). (Luthans, 2002), the behavior of leaders can describe in the field of organizational behavioral science as a theoretical study of micro nature, while the organizational theory of the study is theoretical and its applications are macro and in the field of science (Personnel Human Resources) are applied applications in the discussion are micro. (Sharif, Ashraf and Khan, 2013) empowerment, work-life policies, training and organizational behavior development (OCB) are important factors to improve performance. The development human resource theory concept (Human Resources (HR)) is a theoretical and practical perspective on human resources (HR) that have a different footing. Leadership behavior refers to several indicators according to (Sahertian, 2010), among others, as follows: (1) Idealized influence/attributed, (2) Idealized influences/behaviors, (3) Inspirational motivation, (4) Intellectual stimulation, (5) Individualized considerations.

\subsection{Work Environment}

The work environment is the environment of employees or workers in carrying out their daily work. A conducive work environment provides a sense of security and enables employees optimally. (Masoud and Hmeidan, 2013) training, empowerment, motivation, management support and technology services significantly increase employee performance. Specifically, the dimensions of the work environment are the most significant predictors of the performance of hotel service staff in Amman, the capital of Jordan. Technology treatment in an environmental perspective is carried out to compare different technology choices for management planning used for environmental evaluation, (Voronova, Moora and Loigu, 2011). Work environments such as communication flows, managed workloads, availability of information in workplaces that are free from hazards and are positively related to the employee commitment in improving performance. The indicators of work environment are (1) Work atmosphere, (2) Relationships with colleagues, (3) Relationships between subordinates and leaders, (4) Availability of facilities for employees. This research uses a questionnaire to obtain the data and measured using the modified Likert scale 1-5. The samples are taken using the Census method and taken 128 civil servants Regional Planning Agency of Aceh Province. The analysis technique uses Structural Equation Model (SEM) using SPSS 16.0 and Amos 21.0. The validity test of the instrument is conducted using Confirmatory Factor Analysis (CFA) of each construct, that is by looking at the Loading Factor value of each indicator and the results of each statement item have a value> 0.6. The reliability test uses the following formula

Construct Reliability $=\frac{\left(\sum \text { std.loading }\right)^{2}}{\left(\sum \text { std.loading }\right)^{2}+\sum_{e i}} \ldots$ (1)

While the extract variants can be calculated using the following formula:

Variance Extracted $=\frac{\sum \text { std.loading }}{2}$ 


\section{Results And Discussion}

The results of the full model 1 analysis (initial model) using SEM analysis are shown in figure 2. The calculation results that the goodness of fit index shows that of the eight criteria evaluated, only one criterion has not been fit, namely AGFI.

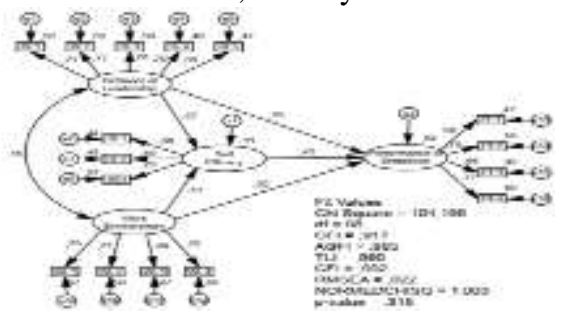

Fig. 1. AGFI

Table 1. Direct, Indirect and Total Influences

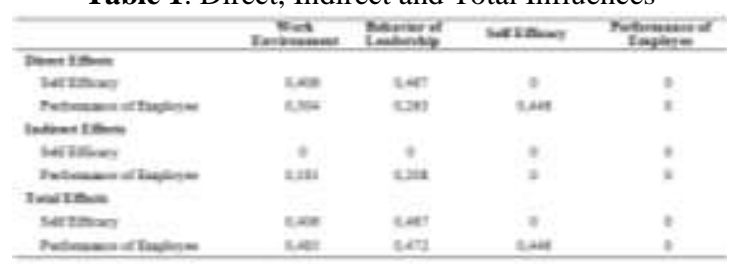

Table 1 reveals that the direct influence of leadership behavior on self-efficacy is 0.467 and on employee performance is 0.263 . Then the influence of the work environment on selfefficacy is 0.406 and on performance is 0.304 . While the effect of self-efficacy on the employee performance is 0.446 . In addition to direct influence, indirect effects can also be seen in Table 5.21 that consist of indirect effect between exogenous and endogenous variables. Indirect influence between leadership behavior on employee performance is 0.208 . Then the indirect effect between the work environment on performance is 0.181 . The total influence between leaders behaviors and employee performance is 0.472 . The total influence between the work environment and employee performance is 0.485 . Based on the results of the intervening effect testing, the relationship between leadership behavior and employee performance is mediated by the self-efficacy. The significance value of Sobel test is 0.012. This means that the significance value is lower than the level of significance of $5 \%$ or 0.05 . It means that self-efficacy mediates the relationship between leadership behavior and employee performance partially. The results of the intervening effect indicate that the significance value of the Sobel test is 0.014. This means that the significance value is lower than the significance level of $5 \%$ or 0.05 . It means that self-efficacy can mediate the relationship between the work environment and employee performance partially.

\section{Conclussion}

The result of the study indicate that leadership behavior and work environment have an effect on self efficacy. Thus, this study can strengthen several previous studies as previously described, so that these findings theoretically add or strengthen theoretical variables that contribute to self-efficacy. Self-efficacy mediates the relationship between leadership behavior and employee performance partially, and self-efficacy can mediate the relationship between the work environment and employee performance partially. 
This study is theoretically expected to provide an overview of a comparison to strengthen or weaken some of the previous studies which are used as the references.

\section{References}

[1] Armstrong, S. (2014) HANDBOOK OF HUMAN RESOURCE MANAGEMENT. United Kingdom: CLA. doi: 10.1007/s10551-011-1141-1.

[2] Bandura, A. (1994) 'Self-Efficacy', in Encyclopedia of human behavior (Vol. 4th edn. New York: Academic Press, pp. 71-78. doi: http://dx.doi.org/10.1016/B978012164730-8/50095-2.

[3] Bernandin, H. J. and Russel, J. A. (2013) Human Resource Management. New York: McGraw Hill Inc.

[4] Hasibuan, H. and Malayu, S. . (2008) Manajemen Sumber Daya Manusia. Jakarta: Bumi Aksara.

[5] Hersey, P. and Blanchard, K. (1994) Manajemen Perilaku Organisasi : Pendayagunaan Sumberdaya Manusia. Terjemahan. Edited by A. Dharma. Jakarta: Erlangga.

[6] Jayaweera, T. (2015) 'Impact of Work Environmental Factors on Job Performance, Mediating Role of Work Motivation: A Study of Hotel Sector in England', International Journal of Business and Management, 10(3), pp. 271-278. doi: 10.5539/ijbm.v10n3p271.

[7] Kreitner, R. and Kinicki, A. (2004) Perilaku Organisasi, Edisi Pertama. Jakarta: Salemba Empat.

[8] Luthans, F. (2002) 'The need for and meaning of positive organizational behavior', Journal of Organizational Behavior, 23(6), pp. 695-706. doi: 10.1002/job.165.

[9] Mangkunegara, A. P. (2005) Perilaku dan Budaya Organisasi. Bandung: Refika Aditama.

[10] Masoud, E. Y. and Hmeidan, T. A. (2013) 'The effect of perceived work environment on frontline employee's service recovery performance: the case of four and five star hotels in jordan', European Scientific Journal, 9(11), pp. 129-147.

[11] McDonald, V. . and Lawton, P. . (1977) Improving Management Performance: The Contributions of Productivity and Performance Measurement”. Local Government management Project. Series B.

[12] Rampersad, H. (2006) Personal Balanced Scorecard. Jakarta: PPM Manajemen.

[13] Sahertian, P. (2010) 'Perilaku Kepemimpinan Berorientasi Hubungan Dan Tugas Sebagai Anteseden Komitmen Organisasional, Self-Efficacy Dan Organizational Citizenship Behavior (OCB)', Jurnal Manajemen dan Kewirausahaan, 12, pp. 156169.

[14] Sharif, M. T., Ashraf, Z. and Khan, M. A. (2013) 'The impact of work life policies ,empowerment and training and development on employee performance with the mediating role of organizational citizenship behaviour ( OCB )', African Journal of Business Management, 7(17), pp. 1618-1624. doi: 10.5897/AJBM11.1951.

[15] Ulrich, D., Younger, J., Brockbank, W. and Ulrich, M. (2012) HR From the Outside In: Six Competencies for the Future of Human Resoureces. New York: McGraw Hill Inc.

[16] Voronova, V., Moora, H. and Loigu, E. (2011) 'Environmental assessment and sustainable management options of leachate and landfill gas treatment in Estonian municipal waste landfills', Management of Environmental Quality, 22(6), pp. 787-802. doi: $10.1108 / 14777831111170876$. 
[17] Wood, W. (1998) Organizational Behaviour, A Global Perspective. New York: John Wiley \& Sons Andbulia, Ltd. 